\title{
How to guarantee food supply during pandemics? Rethinking local food systems from peri-urban strategic agents' behaviour: The case study of the Barcelona Metropolitan Region
}

\author{
¿Cómo garantizar el suministro de alimentos durante las pandemias? \\ Repensar los sistemas alimentarios locales desde el comportamiento \\ de los actores estratégicos peri-urbanos: El caso de estudio de la Región \\ Metropolitana de Barcelona
}

\author{
Sònia Callau-Berenguer ${ }^{1}$ \\ Anna Roca-Torrent ${ }^{2}$ \\ Josep Montasell-Dorda ${ }^{3}$ \\ Sandra Ricart ${ }^{4^{*}}$ (iD
}

\begin{abstract}
The Covid-19 pandemic has acted as a warning for the world's current food system, especially in urban contexts with global food dependence. This article aims to analyse the food system behaviour of the Barcelona Metropolitan Region (in the northeast of Spain) during the first stage of the pandemic by deepening the behaviour of different peri-urban agricultural areas in which local food supply is promoted. Semi-structured interviews to 11 entities and institutions located in the peri-urban area of the BMR based on its productive and management profile have been carried out from March to May 2020. The results obtained highlight the socio-economic, environmental, and health perspective of food supply during the pandemic. Main results show 1) shortcomings in the operation and logistics of the metropolitan food system; 2) the complicity between the local producer and the urban consumer through new sales and distribution initiatives, 3 ) the role of peri-urban agricultural areas for ensuring food supply and land preservation, and 4) the need to initiate cooperation and mutual aid activities between the different agents involved in the food system. Furthermore, agents underlined the need for rethinking the agroeconomic model to strengthening the producer-consumer nexus and promoting local food policy based on food sustainability, sovereignty, and governance.
\end{abstract} Spain.

Keywords: pandemic; local food supply; behaviour; food governance; Barcelona Metropolitan Region;

\section{Resumen}

La pandemia del Covid-19 ha supuesto una advertencia para el sistema alimentario actual a nivel mundial, especialmente en contextos urbanos con dependencia alimentaria global. Este artículo tiene como objetivo analizar el comportamiento del sistema alimentario de la Región Metropolitana de Barcelona (en el noreste de España) durante la primera etapa de la pandemia, profundizando en el comportamiento de

\footnotetext{
1 Territorial Agricultural Directorate, Barcelona Provincial Council, Barcelona, Spain. callaubs@diba.cat

2 Geography Department, University of Girona, Girona, Spain. anna.roca@udg.edu

3 Catalan Institution of Agricultural Studies, Barcelona, Spain. montaselldj@gmail.com

4 Interuniversity Institute of Geography, University of Alicante, Alicante, Spain. sandra.ricart@ua.es. * Corresponding author
} 
diferentes áreas agrícolas periurbanas en las que se promueve el suministro local de alimentos. Entre marzo y mayo de 2020 se realizaron entrevistas semiestructuradas a 11 entidades e instituciones ubicadas en el área peri-urbana de la BMR en base a su perfil productivo y de gestión. Los resultados obtenidos destacan la perspectiva socioeconómica, ambiental y de salud del suministro de alimentos durante la pandemia. Los principales resultados muestran 1) deficiencias en la operación y logística del sistema alimentario metropolitano; 2) la complicidad entre el productor local y el consumidor urbano a través de nuevas iniciativas de venta y distribución, 3) el papel de las áreas agrícolas periurbanas para asegurar el suministro de alimentos y la preservación de la tierra, y 4) la necesidad de iniciar actividades de cooperación y ayuda mutua entre los diferentes agentes implicados en el sistema alimentario. Así mismo, los agentes subrayaron la necesidad de repensar el modelo agroeconómico para fortalecer el nexo productor-consumidor y promover con ello la política alimentaria local basada en la sostenibilidad, la soberanía y la gobernanza alimentarias.

Palabras clave: pandemia; suministro local de alimentos; comportamiento; gobernanza alimentaria; Región Metropolitana de Barcelona; España.

\section{Introduction}

The impact of the Covid-19 pandemic is not limited to the direct threat that the virus imposes on health, but to food supply through the disruptions affecting local and national food systems and economies (Bené et al., 2019). Most countries have limited their economic activity exclusively to meeting citizens' basic needs, which can be summarized in three main sections: healthcare, essential utilities, and services (such as electricity, water, waste management, and food supply). How to guarantee these essential utilities and services when facing future crises affecting the food supply? In this context, some proposals about designing new models of food production and consumption that are less dependent on distribution and logistics networks at a global level have been discussed. Furthermore, strengthening the resilience of local food systems in the face of multiple emergencies that may occur, whether health or climate type, appears necessary and opportune (Amjath-Babu, Krupnik, Thilsted and McDonald, 2020; Pareek, Dhankher and Foyer, 2020). Some expert voices consider that a direct relationship exists between the current health crises and the agro-industrial model based on the dispersion of new pathogens initially confined in ecosystems that are nearly sealed off to humans (Andersen, 2020). Whether or not this is the cause of epidemics like the current one, the prevailing food production model, distribution, and consumption seems in crisis and has been put to the test on ensuring food supply.

Food systems have been experiencing transformations due to their increased orientation towards globalized markets and changes in consumption patterns (Arnalte-Mur et al., 2020). In recent decades, several cities worldwide have committed themselves to improve food systems (understood as the set of activities of the agri-food chain that begins with food production, continues with processing, distribution, sale, and consumption, and ends with waste disposal). The commitment has also included introducing food in terms of health and around urban policies to strengthening the proximity of consumption and reorient farmer-citizen relationships around agriculture and food. For many local governments, the 2015 Milan Urban Food Policy Pact (http://www.milanurbanfoodpolicypact.org/), which advocates an international protocol for staging new urban planning based on the principles of sustainability and social justice, represents the push and the final drive to achieve more sustainable food systems (IPES Food, 2018). With the horizon set in the coordination of initiatives aimed at ecological transition and the struggle against climate change, as well as meeting the Sustainable Development Goals for 2030 and the New Green Deal, urban food policies must be able to ensure the right to food that calls for the mobilization of local and regional players and the collaboration and participation of public bodies and citizens.

Although food systems face socio-economic, environmental, and health challenges, public policies and government institutions present fragmented and stagnant initiatives (Candel and Biesbroek, 2018). Ensuring food sovereignty requires all local and regional stakeholders' mobilisation and involvement and close collaboration between the public and private sectors (Kahiluoto, 2020). However, the food sector also needs to embrace awareness, have the will, and make agreements between government institutions and organised civil society (López and Álvarez, 2018). This complexity is palpable in multifunctional urban and peri-urban agriculture that can supply the public with fresh products and guarantee socio-environmental services such as biodiversity, landscape, or the support of culture and leisure. Consequently, urban and periurban agriculture are at risk of disappearing due to the growing and intense competition for land uses in 
which is difficult to explore food supply alternatives or implement strategies and tools capable of increasing society's resilience based on cross-sectional (along the food chain) and inclusive (adding the demands of society to the public-private binomial) approaches. This article aims to analyse the food system behaviour of the Barcelona Metropolitan Region, BMR (in the northeast of Spain) during the first stage of the pandemic by deepening the behaviour of different peri-urban agricultural areas in which local food supply is promoted.

\section{Methodology}

\subsection{Case study}

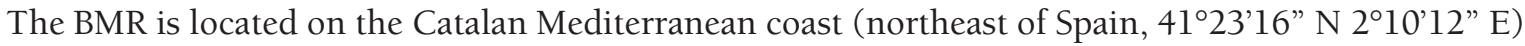
as one of the ten most significant metropolitan areas in Europe. It has an area of 2,348.36 $\mathrm{km}^{2}$, which represents $7.3 \%$ of Catalonia's surface and concentrates a population of 4.89 million inhabitants (64\% of the total population). Administratively and according to the Statistical Institute of Catalonia, it comprises 131 municipalities in the Barcelonès, Baix Llobregat, Vallès Occidental, Vallès Oriental, and Maresme counties. The nuclear area of the BMR is formed by the city of Barcelona and four municipalities: L'Hospitalet de Llobregat, Santa Coloma de Gramenet, Sant Adrià del Besos, and Badalona, constituting an urban conurbation of 2.27 million inhabitants in $146 \mathrm{~km}^{2}$ and an average population density of 15,636 people/ $\mathrm{km}^{2}$ (ahead of cities such as New York, Tokyo, and London) (Verdaguer, 2010). The city of Barcelona, one of the 209 signatory cities of the Milan Urban Food Policy Pact, has been chosen as the World Capital of Sustainable Food for the year 2021 to promote healthy food as an economic opportunity for local trade and farming and to highlight the strategic nature and struggle against the climate emergency.

There are different entities in charge of management of the BMR's agricultural area: the Sabadell Agricultural Park (1993), the Baix Llobregat Agricultural Park (1998), the Gallecs Natural Interest Area (2009), the Montserrat Rural Park (2018) and the Pla de Palou Agricultural Area (2015). The Baixa Tordera Agricultural Area and the Mataró Agricultural Area (Cinc Sènies-Mata-Valldeix) are also being created. In addition, several agrarian revitalization movements ensure the protection of agricultural space and consolidation of a model of agroecological transition (Espelt, Peña-López, Miralbell, Martín and Vega, 2019). Some examples are the Vallès agricultural area, which groups the agricultural soil of the Plana del Vallès and Baix Montseny; the Alimentem Collserola movement, which supports farmers and livestock farmers in promoting their products; the programme for the Agroecological Social Revitalization of Sant Cugat del Vallès, which aims to encourage the reactivation of urban organic farming to promote food sovereignty; and the Cardedeu Agroecological Area, to strengthen and expand the agroecological sector (Figure 1) (Table 1).

Figure 1. Proposals and initiatives for preserving and managing the BMR's agricultural spaces

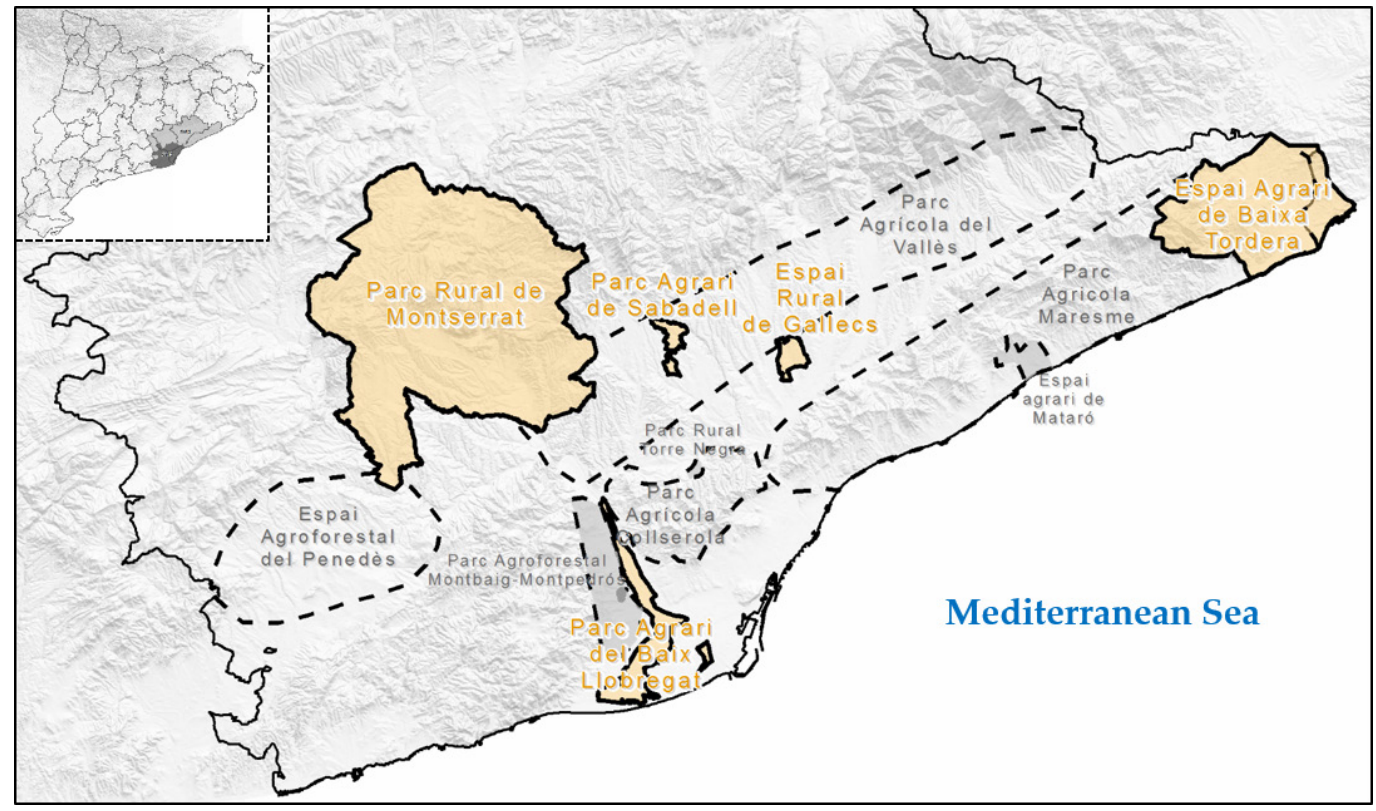

Own elaboration 
Table 1. Characterization of the peri-urban agricultural areas

\begin{tabular}{|c|c|c|c|c|}
\hline Peri-urban areas & Surface (ha) & Promoted by & Planning and projects & Main crops \\
\hline $\begin{array}{l}\text { Baix Llobregat } \\
\text { Agricultural Park, } 1998\end{array}$ & 3,473 ha & $\begin{array}{l}\text { Barcelona Provincial } \\
\text { Council; Baix Llobregat } \\
\text { County Council, Farmers' } \\
\text { Union and } 14 \text { city } \\
\text { councils }\end{array}$ & $\begin{array}{l}\text { - Life Project (1996) } \\
\text { - Management and } \\
\text { development plan, } \\
\text { (2002) } \\
\text { - Special protection plan } \\
\text { (2004 and 2015) }\end{array}$ & $\begin{array}{l}\text { Orchard and } \\
\text { sweet fruit }\end{array}$ \\
\hline $\begin{array}{l}\text { Montserrat Rural Park, } \\
2018\end{array}$ & 34,789 ha & $\begin{array}{l}\text { Barcelona Provincial } \\
\text { Council and } 16 \\
\text { municipalities }\end{array}$ & $\begin{array}{l}\text { - Charter for preservation } \\
\text { and management (2005) } \\
\text { - Framework agreement } \\
\text { between the Barcelona } \\
\text { Provincial Council and } \\
16 \text { municipalities (2018) } \\
\text { - Management and } \\
\text { development plan (2019) }\end{array}$ & $\begin{array}{l}\text { Olive oil, milk } \\
\text { and dairy } \\
\text { products, } \\
\text { cereal, vine } \\
\text { crops, honey, } \\
\text { and range } \\
\text { livestock (cattle, } \\
\text { sheep, and } \\
\text { goats) }\end{array}$ \\
\hline $\begin{array}{l}\text { Pla de Palou Agricultural } \\
\text { Area, } 2015\end{array}$ & 350 ha & $\begin{array}{l}\text { Granollers City Council } \\
\text { and Cardedeu Business } \\
\text { and Technology Support } \\
\text { Centre (CSETC) }\end{array}$ & $\begin{array}{l}\text { - Agreement with the city } \\
\text { council (2011) } \\
\text { - Participative process } \\
\text { (2015) } \\
\text { - Palou Strategic Plan } \\
\text { (2025) }\end{array}$ & $\begin{array}{l}\text { Cereals and } \\
\text { orchard }\end{array}$ \\
\hline $\begin{array}{l}\text { Baixa Tordera } \\
\text { Agricultural Area, } 2017\end{array}$ & 3,222 ha & $\begin{array}{l}\text { Agricultural cooperatives, } \\
\text { farm unions and five } \\
\text { municipalities. }\end{array}$ & $\begin{array}{l}\text { - Framework agreement } \\
\text { Barcelona Provincial } \\
\text { Council (2017) } \\
\text { - Charter for preservation } \\
\text { and management (2017) } \\
\text { - Management and } \\
\text { development plan (2020) }\end{array}$ & $\begin{array}{l}\text { Orchard and } \\
\text { range livestock }\end{array}$ \\
\hline $\begin{array}{l}\text { Mataró Agricultural } \\
\text { Area, } 2019\end{array}$ & 233 ha & $\begin{array}{l}\text { Mataró City Council and } \\
\text { Cinc Sénies-Mata-Valldeix } \\
\text { Agricultural Association }\end{array}$ & $\begin{array}{l}\text { - Charter for the } \\
\text { preservation, } \\
\text { improvement, } \\
\text { development, and } \\
\text { management of the } \\
\text { agricultural area of } \\
\text { the Cinc Sénies-Mata- } \\
\text { Valldeix (2019) }\end{array}$ & Orchard \\
\hline $\begin{array}{l}\text { Cardedeu Agroecological } \\
\text { Area, } 1999\end{array}$ & To be set & Cardedeu City Council & $\begin{array}{l}\text { - Protection project } \\
\text { proposal (2015) } \\
\text { - Agroecological producers' } \\
\text { study (2015) }\end{array}$ & $\begin{array}{l}\text { Cereals, } \\
\text { orchard, milk, } \\
\text { and range } \\
\text { livestock }\end{array}$ \\
\hline $\begin{array}{l}\text { Vallès Agricultural Area, } \\
2004\end{array}$ & 17,555 ha & $\begin{array}{l}20 \text { entities: county and } \\
\text { ecological entities and } \\
\text { hiking and touring } \\
\text { platforms }\end{array}$ & $\begin{array}{l}\text { - Collective protection } \\
\text { project (2005) } \\
\text { - Support manifest (2006) }\end{array}$ & $\begin{array}{l}\text { Cereals and } \\
\text { livestock } \\
\text { production }\end{array}$ \\
\hline
\end{tabular}

Own elaboration

In addition to a diversified agricultural mosaic (Table 2), the BMR also includes sheep, goats, cattle, and chickens. This is confirmed by the quality designation at the regional level available to some agro-livestock products: Denomination of Origin of Alella wine, since 1954; Protected Denomination of Origin of the ganxet bean, in 2011; and the Protected Geographical Indication of chickens and capons, as from 1996. Despite not having specific quality seals, other agricultural productions also enjoy social recognition, such as the oil from Olesa de Montserrat, Baix Llobregat cherries, Prat de Llobregat artichokes, Maresme strawberries or Llavaneres peas. The area also has agri-food transformation and processing centres, mostly aimed at production and export. The BMR acts as the headquarters of national and international agri-food companies and holds a leading position as an agri-food cluster in southwestern Europe (after Lombardy). 
Table 2. Distribution of the agricultural production by types of crops (2019)

\begin{tabular}{|l|r|r|r|r|r|r|}
\hline \multirow{2}{*}{ Production } & \multicolumn{7}{|c|}{ Surface area cultivated (ha) } \\
\cline { 2 - 7 } & Barcelonès & \multicolumn{1}{|c|}{$\begin{array}{c}\text { Baix } \\
\text { Llobregat }\end{array}$} & $\begin{array}{c}\text { Callès } \\
\text { Occidental }\end{array}$ & \multicolumn{1}{|c|}{$\begin{array}{c}\text { Vallès } \\
\text { Oriental }\end{array}$} & Maresme & Total BMR \\
\hline $\begin{array}{l}\text { Cereals, fodders, } \\
\text { and legumes }\end{array}$ & 42.4 & $3,015.9$ & $5,318.3$ & 9,781 & $2,227.7$ & $20,385.3$ \\
\hline Vegetables & 7.6 & 396.1 & 214.6 & 255.4 & $1,734.5$ & $2,608.2$ \\
\hline Fresh fruit & 2.3 & $1,659.6$ & 410.9 & 334.3 & 268.2 & $2,675.4$ \\
\hline Nuts & 0 & 20.8 & 33.2 & 106.4 & 5.9 & 166.3 \\
\hline Vine crops & 3.9 & 281.5 & 36.7 & 153.7 & 218.7 & 694.4 \\
\hline Olives & 0.4 & 622.2 & 240.3 & 315.6 & 24.9 & $1,203.4$ \\
\hline TOTAL & 57.9 & $6,004.8$ & $6,264.1$ & $10,966.7$ & 4,481 & $27,774.6$ \\
\hline
\end{tabular}

Note: The following are not shown on the graph but are included in the total summary: citrus fruits (1.9 ha) and mixed crops defined as the association of vineyards and olive groves with fruit (39.7 ha). Fallow land, unrepresentative, is included in cereals, fodder, and legumes.

Source: SIGPAC 2019. Own elaboration

The BMR has two wholesale markets for fresh food. On the one hand, the Mercabarna (located in Barcelona municipality), devoted to export food commodities and an annual sale of about 1.2 million tons of fruits and vegetables, which constitutes a Food Hub for the Mediterranean. On the other hand, Mercavallès (located in Vallès Occidental county) sells 65,000 tons of fruits and vegetables and devoted to supplying the metropolitan area. Besides, many municipalities have municipal markets for the sale of fresh produce at retail prices: 39 fixed markets in the city of Barcelona and farmers' markets with direct sales by producers and food processors (e.g., the Mataró market with "Harvested at home" points of sale, the Cardedeu market or the Sant Cugat del Vallès market).

However, the constant loss of fertile agricultural land has conditioned agriculture's viability, which suffers great difficulties in being competitive (Roca, Moix and Arellano, 2012; Garcia-Coll and LópezVillanueva, 2018). Between 1990 and 2012, the agricultural surface area was reduced by between 30\% and $50 \%$ causing a loss of production capacity of the metropolitan region's agri-food systems (Cattaneo, Marrull and Tello, 2018). Furthermore, only $12 \%$ of the surface is cultivated permanently, in which the dominant crops are garden vegetables, fruit, vine crops, flower, and ornamental plants in areas close to the coast (northern and southern areas), whereas cereals (nearly $75 \%$ of the agricultural area and intended for preparation of feed for cattle) and livestock operations are in the hinterland. Consequently, the BMR could only meet $16 \%$ of its food self-sufficiency goal, and this situation will get worst considering that about 345 hectares/year have disappeared, which means that almost one hectare is lost every day (Paül, 2009).

The study is focused on 11 entities which include agricultural parks, agricultural areas, councils, and a foundation to highlight the nexus between food supply and land preservation. The two well established agricultural or rural parks are the Baix Llobregat Agricultural Park and the Montserrat Rural Park. The five initiatives to protect agricultural areas currently in process are Pla de Palou Agricultural Area, Baixa Tordera Agricultural Area, Mataró Agricultural Area, Cardedeu Agroecological Area, and Vallès Agricultural Area. Finally, three county councils of the leading agricultural areas (Baix Llobregat, Valles Oriental, and Maresme counties) and an agricultural research foundation (Selmar Plant Defense Group), the last one acting as a meeting point between the producer (farmer) and the consumer (citizen).

\subsection{Data sources}

An initial literature review regarding principal regulations, initiatives, and reports about the agri-food producing sector on different regional scales (including the BMR) has been carried out. Consequently, regional databases have been consulted to characterize the agricultural and socio-economic profile of the case study. Among the documents consulted, it is worth highlighting the Barcelona Metropolitan Strategic Plan (PEMB) (2020), the Promotion strategy for Barcelona's food policy (2016-2019), and the Economic dimension of the food system of the Barcelona Metropolitan Area. Furthermore, recent initiatives oriented 
mainly to encouraging consumption of local products have been considered, such as digital marketing platforms with different forms of sale (e.g., 'The farm at your door', from the Catalonian Farmers' Union; 'The Land's Products Network', from the Barcelona Provincial Council; or the 'We are your farmer', from the Cardedeu town council). Regarding the databases, the focus has been put on the BCN Smart Rural Observatory (Barcelona Provincial Council) and both the Hermes statistical tool (Barcelona region) and Statistical Institute of Catalonia.

In addition, 11 semi-structured interviews were conducted with different stakeholders representing entities and institutions located in the peri-urban area of the BMR selected for their agricultural-productive connotation. For this reason, the interviews focused on a peri-urban combining the nexus between the agricultural sector (from the agrarian revitalization) and the agrarian space itself (planning and management of the territory): three figures of consolidated agrarian-rural protection (Baix Llobregat agricultural park, Montserrat rural park, and Baixa Tordera agricultural area), three figures of agrarian revitalization and dynamization (which are in the process of becoming protected figures at the municipal level (Pla de Palou agricultural area, Mataró agricultural area, and Cardedeu agro-ecological area), the three supra-municipal administrations (city council) working in the promotion and management of the peri-urban and rural area (Baix Llobregat, Vallès Oriental, and Maresme), a supra-local cooperative acting as a driving force for local food consumption (Vallès), and a supra-local research foundation working on the food production and food supply nexus in peri-urban areas (Selmar Plant) (Table 3). An interview script structured in four thematic blocks was used: 1) impacts on the supply and acquisition of food during confinement, 2) changes detected in the ways of marketing food products, 3) development of network support strategies, and 4) coordination of mechanisms of collaboration between farmers to strengthen marketing. Information from the literature review has been used as a database to be discussed during the interviews.

Table 3. Semi-structured interviews

\begin{tabular}{|c|c|c|c|c|c|}
\hline Stakeholder & Date & Tool & $\begin{array}{c}\text { Time } \\
\text { (minutes) }\end{array}$ & Interviewee & ID code \\
\hline $\begin{array}{l}\text { Baix Llobregat } \\
\text { Agricultural Park }\end{array}$ & $12 / 04 / 2020$ & By phone & $69^{\prime}$ & $\begin{array}{l}\text { Organic vegetable producer } \\
\text { and member of the } \\
\text { Catalonian Farmers' Union }\end{array}$ & Interview1 \\
\hline $\begin{array}{l}\text { Montserrat Rural } \\
\text { Park }\end{array}$ & $30 / 03 / 2020$ & Videoconference & $65^{\prime}$ & $\begin{array}{l}\text { Head technician of the Rural } \\
\text { Park }\end{array}$ & Interview2 \\
\hline $\begin{array}{l}\text { Pla de Palou } \\
\text { Agricultural Area }\end{array}$ & $12 / 05 / 2020$ & By phone & $49^{\prime}$ & $\begin{array}{l}\text { Technician of the Granollers' } \\
\text { City Council }\end{array}$ & Interview3 \\
\hline $\begin{array}{l}\text { Baixa Tordera } \\
\text { Agricultural Area }\end{array}$ & $12 / 05 / 2020$ & Videoconference & $45^{\prime}$ & $\begin{array}{l}\text { Tutor training cycle } \\
\text { agroecological production }\end{array}$ & Interview4 \\
\hline $\begin{array}{l}\text { Mataró Agricultural } \\
\text { Area }\end{array}$ & $18 / 05 / 2020$ & By phone & $55^{\prime}$ & $\begin{array}{l}\text { Conventional vegetable } \\
\text { producer (Farmers' } \\
\text { Association) }\end{array}$ & Interview5 \\
\hline $\begin{array}{l}\text { Cardedeu Agro- } \\
\text { ecological Area }\end{array}$ & $24 / 04 / 2020$ & Videoconference & $75^{\prime}$ & $\begin{array}{l}\text { Cardedeu City Council } \\
\text { technician }\end{array}$ & Interview6 \\
\hline $\begin{array}{l}\text { Vallès Agricultural } \\
\text { Area (cooperative) }\end{array}$ & $30 / 04 / 2020$ & By phone & $57^{\prime}$ & $\begin{array}{l}\text { Technical director of } \\
\text { the Franqueses Vallès } \\
\text { Cooperative }\end{array}$ & Interview7 \\
\hline $\begin{array}{l}\text { Baix Llobregat } \\
\text { County Council }\end{array}$ & $12 / 04 / 2020$ & By e-mail & & $\begin{array}{l}\text { Head of agro-territorial } \\
\text { revitalization }\end{array}$ & Interview8 \\
\hline $\begin{array}{l}\text { Vallès Oriental } \\
\text { County Council }\end{array}$ & 04/05/2020 & By e-mail & & Head technician & Interview9 \\
\hline $\begin{array}{l}\text { Maresme County } \\
\text { Council }\end{array}$ & $18 / 05 / 2020$ & By phone & $69^{\prime}$ & $\begin{array}{l}\text { Organic vegetable producer } \\
\text { and member of the Farmers' } \\
\text { Union }\end{array}$ & Interview10 \\
\hline $\begin{array}{l}\text { Selmar Plant Defense } \\
\text { Group (agricultural } \\
\text { research foundation) }\end{array}$ & $18 / 05 / 2020$ & By phone & $45^{\prime}$ & $\begin{array}{l}\text { Head technician and } \\
\text { investigator }\end{array}$ & Interview11 \\
\hline
\end{tabular}


The interviews were conducted between March and May 2020 by telephone or online, depending on each interviewee's needs and availability. The sessions lasted between 45 and 75 minutes. They were audio-recorded and transcribed.

\subsection{Data analysis}

Thematic analysis has been used to qualitatively analyse and evaluate non-empirical data (such as the semi-structured interview transcripts that formed our dataset), and to identify and organise the discrete ideas within the transcripts and outlining patterns in the data, but also indicating their relative frequency and relevance (Ricart, Arahuetes, Villar, Rico and Berenguer, 2019). A SWOT analysis (Phadermrod, Crowder and Wills, 2019) has been applied to evaluate the BMR food system's capabilities and draw up strategies and actions to capture the benefits and opportunities of the local food process. Strengths and Weaknesses refer to those characteristics of the food system that give it an advantage or disadvantage at internal level, while Opportunities and Threats refer to those external elements (from socioeconomic and environmental nature) that could cause troubles or challenges for the food system.

\section{Results}

\subsection{Role, organization, sales systems and collaboration between stakeholders}

Participants emphasized the importance of public administrations' direct actions to support producers and provide information (e.g., web portals and documentation informing consumers about local production. Furthermore, some actions have been focused on providing institutional support (driving economic promotion and campaigns for fostering consumption of local products) or identifying systems of management of points of sale of local products (in markets) or collective sale (distribution and logistics platforms). As a result, it has been possible to decide on the functions of the already consolidated private initiatives for agricultural management and revitalization in terms of proximity. In contrast, the interviewees with profiles closest to farmers (Interview 1, 10) attach little value to institutional initiatives to provide timely assistance in this crisis. Before the compulsory confinement policies, there were already difficulties in selling in street markets, despite being a municipal area of the domain (Interviews 4 and 5). In this sense, many councils decided to close them to take on the (new) safety measures, while privately run supermarkets became the primary source of food supply for most of the population. This situation has made it difficult for fresh and local produce to find outlets at the peak of production (causing severe damage in some agricultural subsectors). It has also brought to light the high level of knowledge of the food system that stakeholders have and their ability to interrelate, organize and, although only in some cases, associate to place agri-food products where they can be more valued and a better price attained. Furthermore, all the agents interviewed are aware of consumers' growing interest in purchasing healthy foods. In that regard, it highlights the need to seek permanent solutions that, beyond the need to address crises such as that produced by Covid-19, which require social distancing, enable expansion of existing marketing options to distribute locally grown food to the entire population.

Representatives from production areas (Interview 1, 10 and 5) focused on their business, producing quality products and placing little or no value on help from the government. They are critical of the financial support offered by public administrations and the innovation and research sector that they consider an interested party and at the agro-industrial model's service. Despite the similarities between agricultural producers, some differences have been observed. Agro-ecological producers (Interviews 1 and 10) are accustomed to networking, helping each other and aiming to complement and diversify the supply for consumption (Calori and Federici, 2020). In contrast, the conventional farmer (Interview 5) tends to work alone and, if he does not sell the product directly, he does so through an intermediary who will place it according to demand and market (usually at a lower price than that which would be achieved via direct sales).

The group of technicians interviewed, regardless of their origin or area of action (education, cooperatives, local council, or association), are a more homogeneous group than the producers. The technicians or managers who represent county-level entities belong to the Land's Products Network of the Barcelona Provincial Council, highlighting the food grown and/or processed within Barcelona's geographical limits. Regardless of the administrative level to which they belong, their functions are agrarian and territorial revitalization, insofar as they comprise part of specific territorial projects. They are usually committed 
and aware of the aim of pursuing the purpose set by the entity. They have developed a high degree of complicity with the people operating in the territory and have become benchmarks within their institutions.

Although both public and private players advocate the same goals, there is no high degree of collaboration and joint work. Producers do not feel involved as a community and have little participatory awareness. They are accustomed to working individually and consider themselves victims of a food system that has excluded and abandoned them. On the other hand, technicians strive to build links with producers via collaboration on shared projects and initiatives. Both producers and technicians recognize the need for more collaboration, so farmers recognize the current collaboration weakness while the technicians try to promote collaboration. What is not considered is who is more responsible for this weakness: producers who do not want to share experiences with other farmers and refuse technicians' role, or technicians who cannot convince or stimulate the producers. However, some examples of collaboration currently exist in the BMR through an already consolidated figure, the "Agricultural Parks", through which bridges of collaboration have been established between farmers and the public administration for over two decades. They are examples of public-private consultation to achieve and implement previously agreed actions requested by much civil society as a source of local food products.

\subsection{Local food as first reaction}

The demand for local food production and the support of digital distribution and local marketing networks that have been established or consolidated during the lockdown has brought to light initiatives and have sought immediate solutions beyond the leading agri-food distributors, the only suppliers to commercial sites during the most critical period of the Covid-19 pandemic. Meanwhile, most of the agents interviewed agreed in highlighting how fast they move to find alternative ways to distribute their products when the usual distribution channels have failed. Accordingly, many of the interviewees agreed in highlighting the opportunities that the Covid-19 pandemic can strengthen the bonds between producers and consumers while showing some scepticism about how to make permanent this nexus. Farmers' markets or baskets at home have been beneficial local strategies during the pandemic as the only possible sales channel for those producers who have had their usual sales network cancelled because of the decree of a state of alarm (sales in restaurants or school canteens) or have suffered a drastic drop in output to the wholesale market (sale via Mercabarna).

Furthermore, most of the interviewees agree in stating that consumers are increasingly demanding local products, as one of the interviewees states: "The Covid-19 crisis has accelerated a change in the pattern of consumption that existed previously but was incipient; now the culture that defends the consumption of local products as a way to contribute to the preservation of the territory and farmers and to ensure a healthy diet has been intensified" (Interview 7). Digital platforms for the distribution of local products have also been promoted, often collectively and supported by municipal and county administrations, as showcases for local products, assuming a part of their distribution (e.g., Productors de Catalunya, [Producers from Catalonia], Arran de terra [near to land], Cistella contra la Covid-19 [basket against the Covid-19]). According to Interview 6, "it is in times of crisis when citizens discover the importance of farming and local products". In the same line, a wide range of factors justifying the importance of encouraging local and $0 \mathrm{~km}$ consumption in the BMR in an emergency context have been identified. The set of proposals have been classified into three main blocks: 1) Actions to prioritize the socio-economic framework (Interviews 2 and 10), 2) Actions focused on the environmental-territorial benefit (Interviews 3 and 4), and 3) Actions in which healthy food justifies the increase in direct sales by the producer, whatever their form of acquisition (Interview 2).

Likewise, most interviewees emphasised the contribution of pre-pandemic direct actions implemented by public administrations when addressing the first months of the lockdown and the compulsory citizen confinement. These actions included 1) information provision (web portals and documentation informing consumers about local production), 2) institutional support (driving economic promotion and campaigns for fostering consumption of local products), or 3) points of sale of local products (in markets and distribution and logistics platforms). However, some interviewees (Interviews 1 and 10) considered that there were already difficulties in selling in street markets before the pandemic, despite some measures at a municipal scale that could be promoted by the city councils (Interviews 4 and 5). In this sense, it should be noted how many councils decided to close the markets during the lockdown based on (new) safety measures, while privately run supermarkets became the main food supply source 
for most of the population. This action motivated the criticism of some agents (Interviews 1, 5 and 10) regarding the insufficient help and the lack of financial support from both the public administration and the innovation and research food sector, considering that both prioritise the expansion of the agroindustrial model in the region.

\subsection{Dimensions of food production}

\subsubsection{The socio-economic dimension: learning from uncertainty}

Overall, agents agree that the Covid-19 crisis has revolutionized how food is supplied in qualitative (interest in healthy products) and quantitative (increased demand) terms. An unprecedented mobilization affects both agricultural professionals and the public and is expressed in new forms of organization, action, and solidarity (Interviews 7 and 10). This increase in demand has been very favourable for agroecological producers, who, although they already had their direct sales channels organized, have increased their sales volume in an extraordinary way (Interview 7). However, conventional producers, who sold their products to large retailers or the wholesale market, have not been favoured by this change in trend that the Covid-19 pandemic has motivated; on the contrary, this production model has had severe difficulties surviving, especially during the first weeks of confinement (March-April 2020). Similarly, those for whom street markets were their primary sales channel were forced to search for new sales strategies that have paradoxically led to access to a new customer profile (Interviews 8 and 9). In the case of producers and/or processors who distributed their fresh and local products to restaurants or school canteens, the health alert seriously affects their traditional sales channels. In parallel, producers who have sought the end consumer and who have had a minimum logistics structure (their shop, consumer groups or cooperatives, face-to-face or online distribution channels, including the use of social networks) have been favoured by the increase in sales.

In general, the need to improve the logistics linked to the product's sale to the consumers has been recognized as a critical point to ensure a better local response to food insecurity scenarios such as those generated by the pandemic (Interviews 3 and 6). Consequently, cooperatives of consumers, cooperative supermarkets or agro-shops have been considered positive options to respond to situations such as that generated by the Covid-19 pandemic. Although much of these initiatives have meant a more remarkable dedication (especially in time and training on new sales channels) by the farmer, it should be noted how agents did not mention this issue. An explanation could be that the Covid-19 pandemic has overturned many standardized patterns in which social networks were not considered an investment but rather a waste of time. However, in a context in which consumers have had limited mobility, and schools and restaurants have not been opened, so the primary source of income and distribution of products disappeared, digital frameworks have been promoted as the only way for the food production sector to survive, increasing the acceptance of this type of tools.

In addition to the concern for the sales channels for local products, most interviewees acknowledged that consumers have had more time to reflect on the origin and quality of agri-food products before choosing from a wide range of products from supermarkets. Consumers have also returned to cooking for themselves, an activity that had been placed on the back burner, in most cases due to lack of timerelated to job responsibilities and commuting (Interviews 10 and 11). In any case, the operational actions that have been sketched in this scenario are eloquent: a) Local food acquisition increased, even for those who before the pandemic were little known and difficult to find; b) Consumers have been open to direct purchase from online platforms that have facilitated distribution at home; c) Individual (agricultural producers) or collective initiatives (associations, consumer groups, unions, networks with institutional support, agricultural cooperatives, etc.) to sell the product has been established to be permanent while generated indirect employment to deal with the tasks of food distribution (despite having to assume costs), and d) Informal and voluntary human capital have been established through digital platforms to collect food to be distributed to those most vulnerable or those with mobility restrictions within the metropolitan area.

Concerning structural difficulties and deficits, it should be borne in mind to overcome administrative and regulatory obstacles and to keep markets and other agri-food equipment and services open. Some interviewees (Interviews 2, 3 and 6) agreed on the need to initiate cooperation and mutual aid activities between the different agents involved in the food system, especially those who have support from social 
and solidarity movements that, in large part, have led the marketing process and distribution of local products during the pandemic. Along the same lines, 1) the lack of organization and strategic points for the supply and distribution of local food products (Interviews 1, 4 and 10),2) the lack of ease of procedures and regulations for mobility (Interviews 1, 4 and 10), and 3) the revitalization of new employment niches (Interviews 7 and 11) stands out. There is also a permanent bias with the other echelons of the agri-food chain and the administration regarding strengthening collaboration agreements with the local socio-economic layout. On the other hand, the emphasis is placed on the collapse suffered of some producers and/or distributors (Interview 7) to deal with the new and growing demand at the beginning of the pandemic. Luckily, this was offset by the formulation of a battery of actions to support farmers. Some actions came from cities (Som la teva pagesia [We are your farmers] -located in Cardedeu. Other initiatives came from associations and consumer groups that voluntarily took on the tasks of collection and distribution, or from public entities that prioritized specific actions and social assistance, such as a call for solidarity for artichokes in El Prat de Llobregat, "calçots" (a type of green onion) in the Baix Llobregat, flowers and ornamental plants in the northern Maresme, milk from the Vallès Oriental county "Som la llet" [We are the milk] or the geolocation map of points of sale of foods of proximity in the Vallès county.

\subsubsection{The environmental-territorial dimension: awareness and action}

The main operational actions identified by the agents are a) The diversity of food production systems (organic, agro-ecological, integrated production, conventional) that facilitates a broad and plural range of consumers, b) Saving of environmental costs arising from the transportation, storage, refrigeration, packaging of local products, and c) The consumer's awareness regarding the need to buy local products. Overall, agents considered that this last point (consumer awareness of local products) has changed according to the phases of confinement established during the first months of the pandemic (a total of 4 phases). At first (phase 0) and for fear of running out of the commodity, there was a tendency to hoard, for example, potatoes; later and because of a deeper reflection on self-consumption of food, seedlings are acquired, and part of the garden is devoted to orchards and self-consumption of vegetables (Interview 7).

Most of the interviewees (Interviews 2, 3, 4, 6, 7, 10 and 11) also recognized society's ability to respond to the food insecurity generated by the pandemic by a) Supporting small and mid-size family farms that, in addition to assuming the productive function, preserve the territory, manage the landscape, and develop an essential environmental role, b) Recovering balconies, terraces, and gardens as spaces for more immediate self-consumption, or c) Conserving agricultural spaces around cities to ensure local food under the criteria of food sovereignty and farmers' resilience. Reactions are plural and embrace different forms that have in common the improvement of food production via a local urban sustainability policy (Interviews 8 and 9). Lastly, the synthesis of the difficulties and structural deficits highlighted by the agents makes it possible to identify: a) The absence of stable political decisions beyond one-off subsidies and support to boost more fair, supportive, and sustainable forms of trade (Interviews 1 and 2), b) The social impetus needed to strengthen the protection of agricultural land on the outskirts of cities as a guarantee of food supply within the framework of urban and territorial planning (Interviews 4, 5 and 6), and c) The coordination of a richly diverse local and regional food culture is resilient to environmental and public health risks, and with a cohesive and cross-sectional profile (Interviews 10 and 11).

\subsubsection{The healthy dimension: the 'proximity' benefits}

All interviewees emphasized how the pandemic has promoted a reflection by both producers and consumers about food quality and food supply in crisis times (Interviews 1, 5, 7, 10 and 11). The Covid-19 pandemic scenario has made people aware of the importance of the quality of life in cities and their dependence on local food (Interviews 8 and 9) and, in return, verified the existence of problems and difficulties in accessing food or situations of risk due to the excessive pollution generated by the mobility of urban life (Interviews 1, 7 and 10). Therefore, in a compulsory and non-consensual way, food has been valued, and home cooking has been re-evaluated. Decisions have been taken to consume more local products, either by purchasing them online or from cooperatives or local markets, which have, so far, been under-used but which have proved successful for both producers and consumers. In any case, most of the interviewees point out that all this can be due to a reaction of fear to the contagion, the anxiety of leaving home, and the attempt to avoid population concentrations, without considering that after this reaction, a permanent 
attitude in the same line could be ensured (Interviews 7, 10 and 11). Lastly, the alert for the consequences of the Covid-19 pandemic has also opened a debate about the validity of the urban organisation's forms about how citizens get around, how they work, and how they eat. Once again, the concept of "proximity" is imposed as the critical aspect of urban planning and sustainable planning, facilitating access to the various social functions of the congested city and draws new maps of daily life for eating (Interview 7).

\subsection{Local food security and new producer-consumer relationship}

According to the interviewees, the lessons learned from the Covid-19 pandemic confinement lead to a range of responses and propose an exercise in discussion and public awareness to assess current policy at the local and regional level and on different fronts open to discussion and action: a) Coordinate food education strategies in schools (Interview 7), b) Promote a common and supportive framework for expanding and retaining local, sustainable and ethical food consumption (Interviews 2 and 10), c) Promote agroecological culture (less waste and dietary change, essential elements for supporting the new food model) to make the management of the production-consumption nexus more robust (Interviews 4 and 5), or d) To design stable groups of stakeholders in food systems that promote mechanisms of collaboration and resilience in an equitable manner (Interview 1, 7 and 9).

The interviews' analysis has made it possible to set up a matrix of relationships between internal and external factors that portrays the existing interrelationships between the agents interviewed (alliances and conflicts) and their assessment of future challenges such as those generated by the Covid-19 pandemic. On the one hand, the SWOT analysis shows the territorial components of food that are moved by an atypical and circumstantial context (the pandemic); on the other hand, it highlights the agents' functions representing food production and the scenarios they intuit in the mid- and long-term. The combination of the four variables involved in the SWOT analysis (Figure 2) enables us to glimpse how producers are expectant and tend to respond reactively and convey their fragility and opportunities to seek solutions and outsourcing part of the process of food distribution to the final consumer unhindered. Moreover, and always according to the interviewed agent's profile, the consumer (who is not directly represented in the sample) receives random and often confusing information. However, they show some awareness of the agri-food supply, so they can study the range of consumption possibilities and act accordingly.

Figure 2. SWOT analysis of the urban food system during the Covid-19 from the producer' perspective

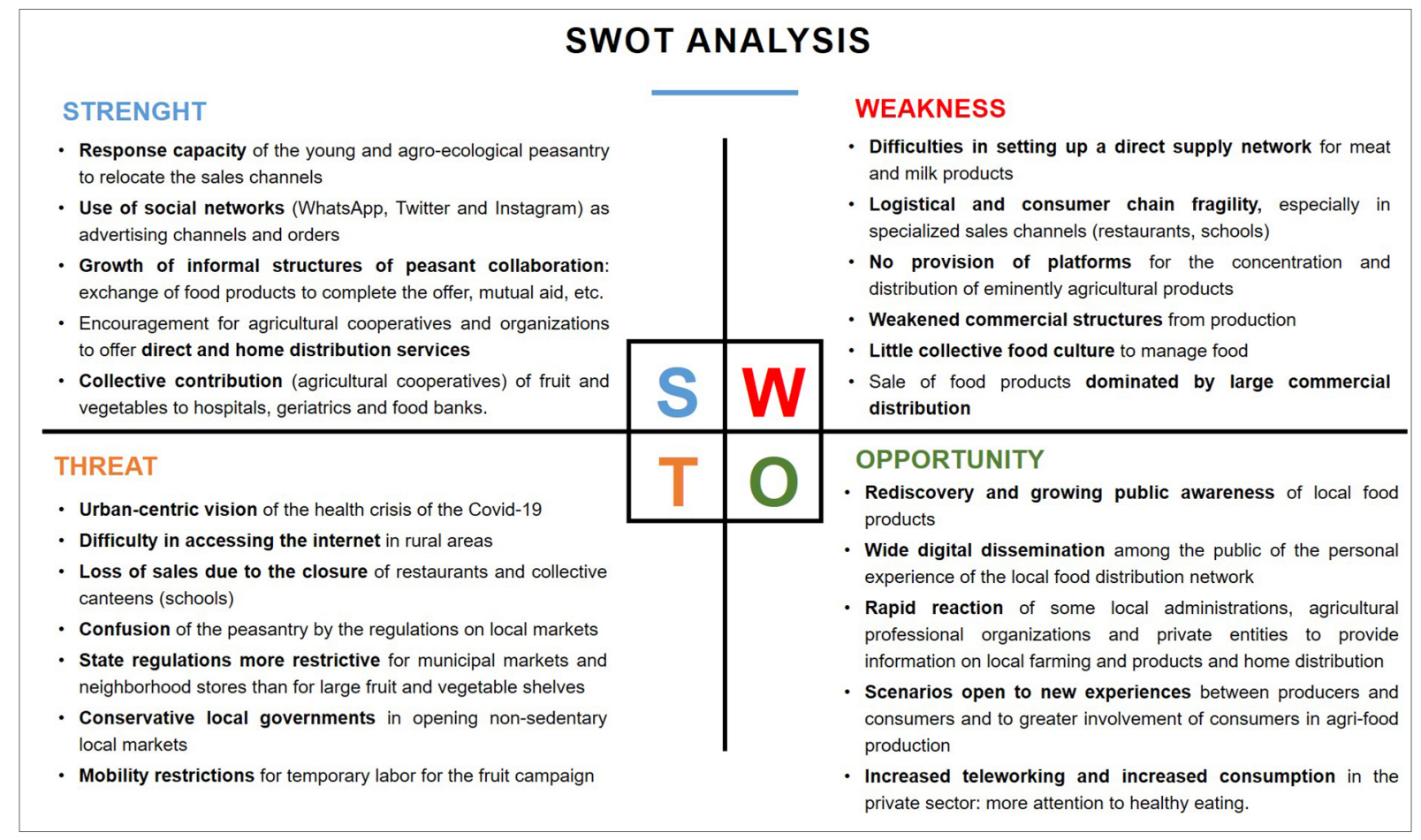




\section{Discussion}

The analysis carried out in this paper has highlighted some relevant issues about local food systems and the management of emergencies, such as that generated by the Covid-19 pandemic. Firstly, the Covid-19 pandemic has highlighted the vulnerability and inefficiency of some BMR's food system activities, exposing shortcomings in operations and logistics. Secondly, the public's awareness has been stirred by promoting new and diverse spaces of complicity between the producer and the consumer and by revaluing often-unknown local and $0 \mathrm{~km}$ products, and that needs to be retained. Finally, the importance of agricultural space preservation entities for revitalising of structures that help to reconfigure food production, distribution, and consumption systems at urban and metropolitan scale has been highlighted. The results obtained lead us to consider whether some significant changes in the social model and food purchasing habits can be identified and whether these changes will eventually materialise in society and extend over time (Giocoli, 2017). Some essential characteristics identified by the interviewees should be highlighted: i) Greater consumer awareness of the intangible values of food (health, education, territory, climate change), ii) More interest in organic and local products, or additional purchase of organic and local products that would be attributed to greater availability of time to buy and cook, iii) The impetus towards interpersonal relationships between producer and consumer, iv) New access and consolidated availability to local food systems to evaluate their strong points and benefits, v) Collaboration and support between producers -mainly in those cases with previous collaborations- in the preparation and distribution of the baskets as new forms of co-managed collaboration.

The analysis of each dimension (socio-economic, environmental-territorial, and health) has made it possible to identify the main challenges that will have to be faced in the future around local food production. In this pandemic context, agents underlined the need for rethinking the agro-economic model to strengthening the producer-consumer nexus and promoting local food policy based on food sustainability, sovereignty, and governance. The lockdown has removed the structure and composition of the agri-food sector as a whole, especially that of fresh and seasonal products, which has seen sales conditions altered and disclosed a predisposition by citizens to know more about and get involved food matters (Tusón, 2014). At the same time, it has forced farmers to reorganize and restructure their organizational and management methods to offer quality products, with health guarantees, quality of service, and with enough thereof (Piorr, Zasada, Doernberg, Zoll and Ramme, 2018). However, their ability to respond and strengthen actions to encourage and diversify local production and promote a stable framework for local, sustainable, and fair food has rarely been positively assessed. Several reasons exemplify this: 1) the lack of collaboration and public-private partnerships (such as those recognized by Interviews 1 and 7), 2) society's lack of involvement in food production (what we eat, how it is supplied, who participates in the food process, etc.) and 3) the weakness of participation and interaction between food producers (Montasell, 2020).

Regarding the last point, it is necessary to position food as an aspect of public policy, opt for collaboration (administration-producers/consumers) and work with the economic sector to look for innovative formulas for the supply-demand organization. Consequently, it would be necessary to move towards food governance and encourage an associative and sharing management style to deal with food logistics on a regional and local scale. Agricultural cooperatives and their associated services may be structures of interest for innovating in the configuration of a food system in terms of proximity, as recognized by most interviewees. The opportunity also invites local food systems to prepare for other warning episodes that could once again shake up an agri-food structure dominated by the distribution sector considered by many to be robust and stable. Therefore, it seems appropriate to intervene, from public policy, to promote healthy, sustainable, and resilient diets while promoting the diversification of agricultural production in terms of health, access, availability, justice and ecology (IPES Food 2019, 2020). The Declaration of Valladolid for the promotion of local agri-food systems to address global risks, gathered in Valladolid on October 1, 2020, was an example of direct action in the face of crises such as Covid-19, considering that the production and distribution of local and sustainable food must be essential for supplying cities and towns, of equal importance to those of water or energy, while promoting territorial planning to protect agricultural soils and good governance between different public policies for the management of global risks. Likewise, other initiatives such as the guide Sistemas alimentarios locales frente a riesgos globales: de la crisis climática a la Covid-19 [Local food systems versus global risks: From the climate crisis to Covid-19] published in September 2020 by Entretantos Foundation and the Network for Cities for Agroecology (Carracosa-García, López-García and Molero-Cortés, 2020). The guide evidencing the impacts generated 
by the lockdown and that need to react in a coordinated way to reduce environmental, socioeconomic and agri-food vulnerability by implementing actions to adapt local food systems to the impacts of global emergencies, while mitigating their causes. Furthermore, the report Xarxes alimentàries locals en temps de Covid-19. Impactes i reptes en un escenari de post-confinament [Local food networks in covid times. Impacts and challenges in a post-confinement] (Batalla et al. 2020) aimed to capture the effects of Covid-19 on local food networks (including production, distribution and consumption) and the challenges that this new scenario poses for each of the poles of the agri-food chain. Proposals focused on diversifying the channels and platforms and include more agents to capture the needs of the local food consumers.

The results of the interviews have shown how, during the period of confinement and within the framework of a Covid-19 pandemic, some decision and actions have been improvised. The public administration (regional and local) has established measures and activated protocols to avoid conflicts over access to food distribution. Local markets have been mainly focusing the controversy. The lack of coordination between the different stakeholders involved in the food system and institutions has been staged in the closure of these essential, closest-to-citizens food services for more than two and a half months, and this has motivated the feeling that the administration, once again, has not considered local food as an essential service, or even as a citizen's right (Malhi et al., 2009). In this regard, it should be recalled that while the state of alarm was declared (France Urbaine Resolis and Terres en Villes, 2020) and to ensure the food supply, many towns and cities closed their weekly outdoor markets (street markets, and among them, farmers' markets). They argued that there was a lack of security measures for both products and access by people. The response of the food production sector was not long in coming from an immediate reaction in the form of initiatives from various groups and informal networks (Calori and Federici, 2020): agricultural entities in the territory (agricultural organizations, cooperatives, NGOs, or universities) join the clamour of agricultural producers, again separated from the decision-making that affects the food system. Some alternatives have been proposed to ensure access to local food systems. One of the most representative examples was the letter of support from 150 organizations addressed to the Spanish government's ministry of agriculture, calling for the reopening of street markets. However, similar examples can be found internationally. According to a Global Partnership report on Sustainable Urban Agriculture and Food Systems (El Salto, 2020), unprecedented interest has been unleashed in short-circuit direct sales, home-grown gardens, and solidarity initiatives to facilitate access to food for vulnerable groups. Examples are Agroecopolis in Greece (via campaigns to promote their products), Reko in Finland (which sponsors proximity through Facebook), OpenFoodNetwork in Australia (where civil society has capitalized on the food issue), or the Ecological Transition Plan for Agriculture and Food in France. The common denominator of these experiences is the desire to develop a collection of recommendations for the improvement of agricultural management in the face of the Covid-19 pandemic, emphasizing the rural nature of agri-food production and claim a regional supply of food products in the city to strengthen nearby agriculture that, at the same time, protects the environment and ensures basic health standards. However, societies that value their food potential the most have led food planning during the Covid-19 pandemic without contradicting the needs of the agroecological transition and the resilience of food systems. In general, and as has been partially demonstrated in the case of the BMR, the local food production sector has been able to react to an extreme situation (pandemic) by position itself while identifying food dependencies in which the consumers are closer and more attentive to local food production (RUAF, 2020). This fact suggests the generation of a new awareness towards the transformation of local food systems by addressing sustainability and food supply, two of the biggest challenges to be faced in the future (Ramonet, 2020).

The analysis of the BMR has enabled stakeholders to recognize the interconnection between food and other strategic sectors, such as transport, digital services, education, health, and urban planning, asking for new strategies and challenges: a) Strengthening the neighbourhood trade network and municipal markets, on a daily and weekly basis as short circuit distribution channels for local products, and b) Diversifying sales platforms and systems to comply with social distancing, avoid crowds and respect confinements. Along this line, in terms of food supply and proximity, Landabasso (2020) proposes the creation of self-sufficient and less vulnerable food production centres, as well as health assurances to rethink and reorganize a territory of inclusion in terms of food. There has also been a growing interest in the value of rural areas and intermediate-sized cities in which food, mobility and health issues are mutually conceived (Gómez-Orea, 2019). Initiatives have emerged such as Moreno's (2020) "la ville du quart d'heure", the 
"20 minutes-20 km Counties" of the Smart Villages project, the agro-urban system as a space to reconnect the city with its metropolitan area (Red Española de Desarrollo Rural, 2016) or the adaptation of Rueda's model of urban ecological planning (Montasell and Callau, 2015). Along this same line, Callau et al. (2017) propose a model for integrating agriculture and food into cities based on the concentration of food products in urban platforms (or food nodes) as an operational and strategic structure. This fits well with the key issues fixed by the Promotion strategy for Barcelona's food policy (2016-2019): 1) specific regulations (and municipal and metropolitan ordinances) to collectively manage food (purchasing food centres, promoting short marketing circuits and direct sales markets); 2) tax breaks and funding support for local food producers; 3) creation of Food Councils as spaces for participation and interaction between public and private stakeholders; and 4) encouraging collaboration and cooperation from municipal actors and networks. The last two points require a review of the concept of food governance as one of the basic principles needed to move towards an ecosystemic view of the agro-urban area able to address food and health risks and uncertainties such as those generated by the Covid-19 pandemic from a participatory way so that the consumer becomes a key player in the construction of the new local food model (Rueda, de Cáceres, Cuchí and Brau, 2012). Food governance calls for commitment and cooperation between every one of the players in the food chain, to generate alliances on different scales, addressing inefficiencies, and promoting consensus, as well as fostering citizen participation in a sustainable and fair food process, as set out in the Milan Urban Food Policy Pact of 2015 (Renting and Wiskerke, 2010). Food governance, therefore, formulates future scenarios that include new forms of usage of productive agricultural space, and distribution and consumption of food, without losing sight of a participatory process based on coordination and cooperation between the different stakeholders involved, from producers to consumers, both vertically and horizontally (Hernández, Ocón and Vicente, 2009; Vidal and Fleury, 2009; Prové, De Krom, and Dessein, 2019).

\section{Conclusions}

THE TURNING POINT: The Covid-19 pandemic has acted as an accelerator for a process of social awareness of the need to ensure food supply. Even as societies become more urbanized, they want to feel closer to their food. As stated by some respondents, consumers are increasingly demanding local products, changing the pattern of consumption that existed previously but was incipient; even as a way to contribute to the preservation of the territory, ensure farmers' activity and promote a healthy diet. They want food that is fresh, less processed, and sustainably sourced. Accordingly, a call for shorter supply chains has intensified during the Covid-19 pandemic. That is, the (in)discriminate mobility of people and goods could be interpreted as a threat: first, because it can favour the expansion of new outbreaks and/or health effects of equal or greater virulence, and second, because mobility and transport contribute to the environmental impact of $\mathrm{CO}_{2}$ emissions which, in turn, puts at risk the supply of imported commodities.

WINDOWS OF OPPORTUNITY: The Covid-19 pandemic has underlined the importance of a robust and resilient food system that functions in all circumstances and can ensure access to a sufficient supply of affordable food for citizens. It has also made us acutely aware of the interrelations between health, ecosystems, supply chains, consumption patterns and planetary boundaries. The Farm to Fork Strategy (European Green Deal) calls for reinforcing local food production by empowering the consumers to choose a sustainable food system in which all actors in the food chain should see this as their responsibility and opportunity. Faced with this scenario and with an eye on the primary and essential resource that food is, this study has focused its analysis on the impact of the Covid-19 pandemic on local food systems and future strategies adapted to emergency contexts. Because of the analysis within the framework of the BMR, it has been claimed that the concern for the health situation has led the public to demand closer (and well-known) food products (especially fresh foods) and organic (safer). Besides, these products should be produced and sold locally, either in (neighbourhood) small shops, buying them online directly from the producer (safer and with a personal, non-branded guarantee) or on local markets as meeting places for social and cultural exchange and food proximity. Most interviewees emphasised the contribution of direct actions implemented by public administrations in the first months of the lockdown: web portals and documentation informing consumers about local production, economic promotion and campaigns for fostering consumption of local products, or promoting points of sale of local products in markets and distribution and logistics platforms. However, some interviewees highlighted how many city councils decided to close the markets during the lockdown based on updated safety measures, while privately 
run supermarkets became the main food supply source for most of the population. All this suggests that in a context of uncertainty, a niche of opportunities can be opened for local food production, sale and consumption structures close to the citizenry. A new consumption pattern that introduces and raises consumers' awareness and makes them part of the food process via the organization and management of distribution and logistics in a sustainable, healthy, and efficient way.

FOOD: A PRIVATE AND GLOBAL BUSINESS OR A PUBLIC AND LOCAL POLICY? The pandemic crisis has been a wake-up call to the globalized model of food production and consumption, in which citizens have been limited in movement due to confinement and fear of contagion while governments have acted on the provision of essential resources, including food. While some municipal governments closed, the outlets of small producers (such as municipal street markets), regional and some municipal governments campaigned to promote and support local products and farming that feeds the population and manages territories. As a result, the weakness of current local production models, and the lack of structures for collaboration in local food production and processing, have been highlighted. Against this backdrop, food governance should be promoted to provide local public policy strategies based on collaboration between public and private actors in the production, processing, and distribution of food sectors. Some examples of collaboration currently exist in the BMR through an already consolidated figure, the "Agricultural Parks", through which bridges of collaboration have been established between farmers and the public administration for over two decades. They are examples of public-private consultation to achieve and implement previously agreed actions requested by citizens as a source of local food products. Following this example, the aim is to move decisively and safely towards local, sustainable, resilient, healthy, safe, and fair food systems improving the production-consumption nexus and being capable of dealing with emergency contexts such as those generated by the Covid-19 pandemic. In this regard, the scope of the BMR is a suitable scenario to test this transition, as it forms a context with a) diversified agricultural production that could provide nearly all the staple foods for daily intake (vegetable garden, fruit, cereals, milk, oil, meat); b) the presence of collaborative structures organized between the economic sector (farming) and public administrations (by way of agricultural parks) and c) a citizenry predisposed to consume local food products. Future works should address some of the limitations of this study, such as the short time period of analysis or the lack of policy review, by extending the research to individual food producers through a survey sample to identify and deepen main concerns and challenges, while using this feedback to check and discuss the SWOT analysis and the agents' perspectives.

\section{Acknowledgments}

The authors would like to thank all technicians, managers, and food producers interviewed for their contribution, very much appreciated.

\section{References}

Amjath-Babu, T.S., Krupnik, T.J., Thilsted, S.H., \& McDonald, A.J. (2020). Key indicators for monitoring food system disruptions caused by the Covid-19 pandemic: Insights from Bangladesh towards effective response. Food Security, 12, 761-768. http://dx.doi.org/10.1007/s12571-020-01083-2

Andersen I. (2020). The United Nations Environment Programme, UNEP, Statement on Covid-19. Retrieved from https://www.unenvironment.org/news-and-stories/statement/unep-statement$\underline{\text { covid-19 }}$

Arnalte-Mur, L., Ortiz-Miranda, D., Cerrada-Serra, P., Martínez-Gómez, V., Moreno-Pérez, O., Barbu, R., ... \& Sumane, S. (2020). The drivers of change for the contribution of small farmers to regional food security in Europe. Global Food Security, 26, 100396. http://dx.doi.org/10.1016/j.gfs.2020.100395

Batalla, L., Correro, A., Hierro, A., Homs, P., Ravera, F, Rivera-Ferre, M.G., \& Sastre, A. (2020). Xarxes alimentàries locals en temps de covid-19. Impactes i reptes en un escenari de post-confinament. Barcelona: Pam a Pam Editorial. Retrieved from https://xarxanet.org/biblioteca/xarxes-alimentaries-locals-entemps-de-covid-19-impactes-i-reptes-en-un-escenari-de-post

Bené, C., Oosterveer, P., Lamotte, L., Brouwer, I.D., de Haan, S., Prager, S.D., Talsma, E.F., \& Khoury, C.K. (2019). When food systems meet sustainability - Current narratives and implications for actions. World Development, 113, 116-130. http://dx.doi.org/10.1016/j.worlddev.2018.08.011 
Callau, S., Montasell, J., \& Vila, J. (2017). Food cells and food nodes. Two new concepts for rethinking traditional urban and food planning practices. The case of Barcelona's Metropolitan Region. In Ch.T. Soulard, C. Perrin, \& E. Valette (Eds.), Toward sustainable relations between agriculture and the city (pp. 111-128). Cham: Springer. https://doi.org/10.1007/978-3-319-71037-2_7

Calori, A., \& Federici, F. (2020). Coronavirus and beyond: empowering social self-organization in urban food systems. Agriculture and Human Values, 37, 616-616. http://dx.doi.org/10.1007/s10460-02010111-y

Candel, J.J.L., \& Biesbroek, R. (2018). Policy integration in the EU governance of global food security. Food Security, 10(1),195-209. http://dx.doi.org/10.1007/s12571-017-0752-5

Carrascosa-García, M., López-García, D., \& Molero-Cortés, J. (2020). Sistemas alimentarios locales frente a riesgos globales: de la crisis climática a la COVID-19. Valladolid: Fundación Entretantos y Red de Ciudades por la Agroecología. Retrieved from http://www.fao.org/urban-food-actions/resources/ resources-detail/es/c/1312581/

Cattaneo, C., Marrull, J.R., \& Tello, E. (2018). Landscape agroecology. The dysfunctionalities of industrial agriculture and the loss of the circular bioeconomy in the Barcelona Region, 1956-2009. Sustainability, 10(12), 4722. http://dx.doi.org/10.3390/su10124722

El Salto (2020). La agricultura valenciana resiste al Covid. Retrieved from https://www.elsaltodiario.com/ agricultura/agricultura-valenciana-resiste-coronavirus-covid-19

Espelt, R., Peña-López, I., Miralbell, O., Martín, T., \& Vega, N. (2019). Impacto de las tecnologías de la información y la comunicación en el cooperativismo agroecológico en Cataluña. Agrícola Econ.Czech, 65, 59-66. http://dx.doi.org/10.17221/171/2018-AGRICECON

France Urbaine Resolis and Terres en Villes (2020). Les villes et l'alimentation en période de pandémie. Expériences françaises. Ministère de l'Europe et des affaires étrangers, Commission nationale de la coopération décentralisée, Banque des territoires. Retrieved from http://terresenvilles.org/villes-etalimentation-en-periode-de-pandemie-experiences-francaises

Garcia-Coll, A., \& López-Villanueva, C. (2018). The impact of economic crisis in areas of sprawl in Spanish cities. Urban Science, 2(4), 113. http://dx.doi.org/10.3390/urbansci2040113

Giocoli, A. (2017). La actividad agraria en el área metropolitana de Barcelona: retos y oportunidades para el planeamiento urbanístico desde la visión agroecológica. In G. Tendero (Ed.), La ciudad agraria. Perspectivas agroecológicas (pp. 103-122). Barcelona: Icaria Editorial.

Gómez-Orea, D. (2019). En el corazón del despoblamiento. Unión de Pequeños Agricultores (UPA). Retrieved from https://www.youtube.com/watch?v=_yzC-6n_FK8

Hernández, V., Ocón, B., \& Vicente, J. (2009). Estudios periurbanos, transición de la ciudad al campo. Ecosostenible, 49, 5-12.

IPES Food (2018). Romper con los sistemas agrarios y alimentarios industriales. Siete experiencias de transiciones agroecológicas. Estudio del caso 2. Retrieved from http://www.ipes-food.org/img/ upload/files/IPES_CS02_1810_WEB_espagnol_tbr.pdf

IPES Food (2019). Hacia una política alimentaria común en la Unión Europea. La reforma y ajuste necesarios para construir un sistema alimentario en Europa. International Panel of Experts on Sustainable Food Systems. Retrieved from http://www.ipes-food.org/pages/CommonFoodPolicy

IPES Food (2020). Covid-19 and the crisis in food systems: Symptoms, causes, and potential solutions. Communiqué by The International Panel of Experts on Sustainable Food Systems, April 2020. Retrieved from http://www.ipes-food.org/pages/covid19

Kahiluoto, H. (2020). Food systems for resilient futures. Food Security, 12, 853-857. http://dx.doi. org/10.1007/s12571-020-01070-7

Landabasso, M. (2020). Conversaciones para una transformación ineludible. Barcelona: ISGlobal. Retrieved from https://blogs.upm.es/covid19upm/2020/04/29/alcaldes-y-alcaldesas-de-variasciudades-espanolas-comparten-iniciativas-para-el-dia-despues/

López, D., \& Álvarez, I. (2018). Hacia un sistema alimentario sostenible en el Estado Español. Propuestas desde la agroecología, la soberanía alimentaria y el derecho a la alimentación 2030-2050. Madrid: Foto Transiciones.

Malhi, L., Karanfil, Ö., Merth, T., Acheson, M., Palmer, A., \& Finegood, D.T. (2009). Places to intervene to make complex food systems more healthy, green, fair, and affordable. Journal of Hunger and Environmental Nutrition, 4(3-4), 466-476. http://dx.doi.org/10.1080/19320240903346448 
Montasell, J. (2020). La pagesia: resilient i solidària a Noticies de la Institució Catalana d'Història Natural. Noticies. 149. Retrieved from https://blogs.iec.cat/ichn/wp-content/uploads/sites/33/2021/05/N149_ web.pdf

Montasell, J., \& Callau, S. (2015). Células alimentarias: Un nuevo instrumento de planificación y gestión de sistemes agrourbanos. In C. Yacamán, \& A. Zazo (Eds.), El Parque Agrario una figura de transición hacia nuevos modelos de gobernanza territorial y alimentaria (pp. 143-164). Madrid: Heliconia.

Moreno, C. (09/03/2020). Un regard urbain sur la crise du Coronavirus. El País. Retrieved from http:// www.moreno-web.net/el-pais-una-vision-urbana-sobre-la-crisis-del-coronavirus-13-mars-2020/

Pareek, A., Dhankher, O.P., \& Foyer, C.H. (2020). Mitigating the impact of climate change on plant productivity and ecosystem sustainability. Journal of Experimental Botany, 71(2), 451-456. http:// dx.doi.org/10.1093/jxb/erz518

Paül, V. (2009). L'ordenació dels espais agraris a Catalunya. Una visió retrospectiva. In A. Ribas (Ed.), La futura llei d'espais agraris de Catalunya. Jornades de reflexió, participació i debat (pp. 39-84). Barcelona: Documenta Universitaria.

Phadermrod, B., Crowder, R.M., \& Wills, G.B. (2019). Importance-performance analysis-based SWOT analysis. International Journal of Information Management, 44, 194-203. http://dx.doi.org/10.1016/j. ijinfomgt.2016.03.009

Piorr, A., Zasada, I., Doernberg, A., Zoll, F., \& Ramme, W. (2018). Research for AGRI Committee Urban and Peri-urban Agriculture in the EU, European Parliament, Policy Department for Structural and Cohesion Policies. Brussels. Retrieved from https://www.europarl.europa.eu/RegData/etudes/ $\underline{\text { STUD/2018/617468/IPOL_STU(2018)617468_EN.pdf }}$

Prové, C., De Krom, M., \& Dessein, J. (2019). Politics of scale in urban agriculture governance: A transatlantic comparison of food policy councils. Journal of Rural Studies, 68, 171-181. http://dx.doi. org/10.1016/j.jrurstud.2019.01.018

Ramonet, I. (25/04/2020). La Pandemia y el sistema mundo. Le Monde Diplomatique. Retrieved from https://mondiplo.com/la-pandemia-y-el-sistema-mundo

Red Española de Desarrollo Rural (REDR) (2016). Smart Villages. Retrieved from: https://enrd.ec.europa. eu/enrd-thematic-work/smart-and-competitive-rural-areas/smart-villages_es

Renting, H., \& Wiskerke, H. (2010). New emerging roles for public institutions and civil society in the promotion of sustainable local agro-food systems 9. European IFSA Symposium, 4-7 July 2010. Viena, Austria.

Ricart, S., Arahuetes, A., Villar, R., Rico, A.M., \& Berenguer, J. (2019). More water exchange, less water scarcity? Driving factors from conventional and reclaimed water swap between agricultural and urban-tourism activities in Alicante, Spain. Urban Water Journal, 16(10), 677-686. http://dx.doi. org/10.1080/1573062X.2020.1726408

Roca, J., Moix, M., \& Arellano, B. (2012). El sistema urbano en España. Scripta Nova, 16(396). Retrieved from http://www.ub.edu/geocrit/sn/sn-396.htm

RUAF (2020). City region food Systems to cope with Covid-19 and other pandemic emergencies. Retrieved from https://ruaf.org/news/city-region-food-systems-to-cope-with-covid-19-and-otherpandemic-emergencies/

Rueda, S., de Cáceres, R., Cuchí, A., \& Brau, Ll. (2012). El urbanismo ecológico: Su aplicación en el diseño de un ecobarrio en Figueres. Barcelona: BCNEcologia.

Tusón, P. (2014). L'autoproveïment d'aliments a Catalunya. És possible la nostra sobirania alimentària? Agrocultura, 55. Retrieved from https://elguaret.files.wordpress.com/2018/08/autoproveimentdaliments-a-catalunya.pdf

Verdaguer, C. (2010). Planificación del desarrollo y perservación de los usos agrícolas en el Gran Londres (Gran Bretaña). Pasos hacia el autoabastecimiento y la agricultura de proximidad en una gran capital europea. Monografia. Estudio técnico ETS Arquitectura de Madrid. Retrieved from http://oa.upm. es/9525

Vidal, R., \& Fleury, A. (2009). Aménager les relations entre la ville et l'agriculture. De nouveaux enjeux territoriaux et une nouvelle approche «agriurbaniste». Urbia, 8, 127-142. 